\title{
Developing English for General Academic Purposes (EGAP) Course in an Indonesian University
}

\author{
Flora Debora Floris \\ English Department, Faculty of Letters, Petra Christian University, \\ Siwalankerto 121-131, Surabaya, East Java, Indonesia \\ e-mail: debora@peter.petra.ac.id
}

\begin{abstract}
This paper discusses the methodology and findings of a needs analysis survey which was carried out in 2005 by English Language Teaching Center (ELTC) of a private university in East Java, Indonesia. Based on the survey of 1,450 students' and 34 teachers' language needs, some implications related to course type, teaching methodology and course materials were made.
\end{abstract}

Key words: needs analysis, material development, English for General Academic Purposes (EGAP)

People can hardly deny that English plays a very important role in this globalized era. It is the most widely spoken language in the world. A good mastery of English can be said to be a prerequisite for the success of developing oneself. Therefore, universities in Indonesia need to prepare their students not only to achieve mastery of their own subjects but also to use English proficiently in oral and written communication.

To meet the demand in a private university in East Java, Indonesia, a policy to use English as a medium of instruction has been set up. It is hoped that the students will achieve the mastery of their content courses and the international language, i.e. English.

However, the English curriculum for the non-English Departments was not sufficient to prepare students to attend classes in English. The objective of the course was merely to enhance the general English proficiency of the students, not to introduce the students to aspects necessary for attending subject classes in English. Moreover, students' enthusiasm in learning English was found to be very low. Therefore, a new curriculum that could improve the students' English proficiency and competency was needed. In addition, the curriculum had to include all important study skills in English that could mirror the real classroom 
activities from different subject-matter classes. In that way, students could be prepared and competent when they had to perform those study skills in English in their subjects. Students would also be more motivated to learn English since they felt that they were taught what they needed.

A task force consisting of three English Language Teaching Center (ELTC) academic staffs was formed to design the new English course. The team understood that effective language teaching and learning could only be achieved when course designers were aware of the participants' needs and capabilities. Thus, needs analysis, defined by Graves (2000, p. 98) as a systematic process of "gathering information about students' needs and preferences, interpreting the information, and then making course decisions based on the interpretation in order to meet the needs", should be a first step carried out before a course begins. The data gathered would be in the form of both objective information and subjective information about the students. Objective information includes "facts about who the learners are, their language ability, and what they need the language for" while subjective information includes "expectations the learners have with respect to what and how they will learn" (p. 104).

This paper further focuses on describing the team's experiences in conducting the needs analysis before developing the materials. Research methodology, findings, discussion and implications of the research would be described in details.

\section{METHODOLOGY}

This study was carried out in January-May 2005 to determine the students' English proficiency, as well as the language and study skills that they needed in order to be able to perform successfully in subject-content classes conducted in English.

Two sets of questionnaires were distributed to students and teachers of the university. The students' questionnaires comprised fourteen questions and were divided into two sections, each of which contained questions related to the profiles of the respondents and their perceived English needs. The teachers' questionnaires comprised six questions and were also divided into two parts, i.e. the teachers' profiles and their students' perceived language needs (refer to the Appendix for the questionnaires).

In addition, to gather more qualitative data, there were semi-structured discussions (interviews) with the students and teachers. The interviewers 
had nine guiding questions, and they could also elaborate the questions to get deeper understanding of what the respondents thought. The interview questions were basically similar to the questions written on the questionnaires.

All instruments above were not derived from any specific sources but developed by the researchers based on their experiences in the English language teaching field. The instruments had been pilot tested and minor amendments had been made.

The subjects of this study were the fourth and sixth semester students and teachers of fourteen non-English departments at the university. Three classes of each department were selected randomly as the sample.

The questionnaires were distributed to 1,450 students and 34 teachers. The survey questionnaires were administered for approximately ten minutes.

A focus group discussion (group interview) was carried out by inviting representatives of teachers and students across the departments. The activity was attended by twenty-five participants. The group interview took about ninety minutes. It yielded further details that were not included in the questionnaires.

The questionnaires were then analyzed using SPSS (version 5) statistical package. The calculations were quantified in terms of percentage. The details obtained from the semi-structured discussions served the purpose of gathering more qualitative data. The findings of the survey conducted were then synthesized to formulate the framework of the proposed English course.

\section{FINDINGS AND DISCUSSION}

From the survey conducted in fourteen non-English departments, some conclusions could be drawn up.

\section{Students}

The majority of the students was twenty up to twenty-one years old (64.1\%) and was in the sixth semester (51.7\%) or fourth semester (48.3\%). A total of $86.8 \%$ of the respondents perceived the mastery of English as very important (51.7\%) and important (35.1\%). 51.4\% of the respondents had been learning English for six up to ten years. Only 25.2\% of them, however, had taken a TOEFL test within the last two years. 58\% of these 
students acquired 453-550 TOEFL score. When asked to rate their proficiency level, the majority of the students thought they had fair proficiency in listening (58.6\%), speaking (61.2\%), reading (58.3\%), and writing (61.5\%). In addition, the interviewees believed that they had sufficient level of grammar competency. Therefore, it could be assumed that the students' level of English proficiency was Intermediate.

Approximately $60 \%$ of the respondents admitted that the level of difficulty for each micro skill of listening was average (fair). While in speaking, $47.7 \%$ of the students found that delivering presentations was very difficult. Some interviewees stated that to give a presentation using English was hard because they had to face the fear of standing in front of many people, to look clever and interesting, and to use a language that they seldom used in their daily life.

When asked about each micro skill of reading, $44.4 \%$ of the learners admitted that they had difficulty in scanning reading texts. Some interviewees confessed that their reading speed was slow because they tried to understand each written word. At the end, these slow readers had problems in their reading comprehension.

Writing an essay was also considered difficult by $48 \%$ of the subjects. Some students interviewed said that it was difficult for them to apply their knowledge of grammar and vocabulary in writing. They already had problems in writing in Bahasa Indonesia (the Indonesian language), thus it was even more difficult for them to write in a foreign language.

When asked to rank the importance of each English skill in relation to their subject matter courses, most students claimed that they needed speaking (45.5\%), listening (32.9\%), reading (18.1\%) and writing (3.5\%) to support their undergraduate study. The majority of student-interviewees also claimed to prefer speaking to other English skills.

To motivate them in learning English, the respondents asked ELTC to include some of the most interesting topics in their future English course book namely entertainment, technology, tourism, career, business, and culture. Another suggested topic was sport (3.6\%). Students interviewed stated that they would be more motivated when topics presented were related to their personal interests.

\section{Teachers}

$52.9 \%$ of the teachers hold bachelor degree, $41.2 \%$ master degree and $5.9 \%$ doctorate degree. The majority (50\%) had been teaching at the 
university for one to five years; while $26.5 \%$ for more than eleven years, $11.8 \%$ for six up to ten years and the rest for less than one year.

It is interesting to note that speaking (32.4\%) and reading (32.4\%) were perceived as the most important skills that could support their students' undergraduate study. Listening (26.5\%) and writing (8.7\%) were also needed for their students' success. Some teacher-interviewees commented that the students of engineering department needed receptive English skills while those of social department should master productive skills.

During the group interview, all lecturers stated that they sometimes (if not often) used English textbooks or handouts in their content classes. They admitted that because of that, they got complaints from their students. These teachers had general impression that most students had low language proficiency so they had problems in understanding the texts provided. In addition, some (if not all) students probably had negative attitude towards the use of English. If the policy of using English as a medium of instruction was implemented, these students would probably feel that they were forced to use or do something that they did not like.

Related to the topics for their students' future English course book, the teachers suggested some of the most interesting topics to be included were career, business, entertainment, tourism, education, and health. Another interesting topic proposed was social issues (5.9\%).

The students' and teachers' responses revealed some interesting points. First, regardless of the major field of study, both students and teachers argued that they needed the mastery of speaking in English. In Indonesia, at the beginning, people needed English reading knowledge in order to catch up with developed countries technologically, economically and politically. Therefore, it was assumed that reading should be the aim of teaching and learning English (Ahmad, 1997, p. 47). However, as the use and functions of the English language continue to grow, now Indonesians need the language to play active roles in the advancement of technology, economy, trade and international politics. As a result, the students should be given opportunities to master English language for communicative purposes. Reading should no longer be the only legitimate focus of learning English because it would make the students less motivated (p. 50).

Another interesting point was that although the majority of the students thought they had fair proficiency in English, the teachers were still in uncertainty whether the students would be ready to enroll in subject-classes conducted in English. This result was similar to the finding of the research 
conducted in 2003 in which 53.34\% among thirty Economics lecturers of the university pointed out that the main obstacle to the implementation of English as the medium of instruction was students' low English proficiency and negative attitudes towards using English (Floris, 2004, p. 70). However, as English becomes progressively promoted as an international language, both teachers and students should first learn to see the value of learning non-language-based subjects, such as Economics or Engineering, by using foreign language. Once they have noticed the advantages of learning subjects such as these in English, they will be motivated to improve their foreign language proficiency. Self motivation undoubtedly plays an important role in learning language.

\section{IMPLICATIONS}

The result of the needs analysis enabled the ELTC team to formulate the design of the new English course that fit into the needs of the target audience, i.e. the students of the non-English Departments. After formatting the design, the team developed the course book. In 2006, pilot projects using the new book were conducted.

\section{Course Type}

There were at least two points that needed to be considered in determining the type of the new English course. First, students of the university were all adults who already had some acquaintances with English and would like to learn the language for communication. Second, as required by the university, the new English course had to prepare the students to be competent in using English in their content classes.

Therefore, ELTC team decided to develop an English for General Academic Purposes (EGAP) course, a branch of English for Specific Purposes (ESP), which according to Dudley-Evans and St John (1998) refers to "any English teaching that relates to a study purpose" (p. 34). In such a course, students whose first language was not English would learn both the language of academic discipline and the study skills required during their academic course.

\section{Teaching Methodology}

There are many ways to teach language. However, to accommodate the students' needs and teachers' or institutional requirements, ELTC 
needed to develop integrated teaching/learning program aimed for communicative purposes.

Communicative Language Teaching (CLT) was selected as the methodological approach of the EGAP course for its distinctive characteristics. First, this CLT methodology aims at communication and emphasizes interaction as both the means and the ultimate goal of learning a language (Larsen-Freeman, 2000). In CLT classes, learners are encouraged to actively engage in trying to make themselves understand and in understanding others. Second, the role of the teachers in CLT is also different from traditional teaching methods. The teachers act only as facilitators, allowing their students to be in charge of their own learning (Larsen-Freeman, 2000). The lecturers set up various communicative situations that the students are likely to encounter in real-life, for example asking clarifications or writing reports. The exercises are in the forms of games, role-plays, problem solving tasks, etcetera. In these exercises, the students are required to communicate their needs and thoughts using the target language. By applying CLT methodology in EGAP researched classes, the students were expected to increase their confidence in using the target language.

\section{Course Materials}

One of the characteristics of CLT approach is the use of authentic texts in the classrooms. Many specialists also view authentic texts as the most essential component of any language course. McGarry (1995, p.3), for example, claims that authentic texts can create a language-rich environment and provide students "with bridges to the real-world of the target language". Such texts can also motivate learners because they are interesting, engaging, and relevant.

The readings of the EGAP course then consisted of authentic materials taken from different sources both printed and on-line. The selection of topics was based on the students' own preferences and teachers' suggestions. The authentic reading texts served as the basic materials for the active communicative tasks.

The tasks themselves integrated listening, speaking, reading and writing skills as far as possible. They were designed to improve the learners' language skills. The students were greatly encouraged to comprehend, produce, and interact in the target language, i.e. English. This was done, for example, by using oral activities such as pair or small group 
discussions in English related to the reading texts. Grammar, provided in each chapter, was linked to the topic of the reading texts and served only as a "reminder" of the language structures.

Computer Assisted Language Learning (CALL) or interactive multimedia was incorporated because it allowed realistic simulations of communicative situations which were in line with the principle of CLT approach. Furthermore, the nature of the multimedia made it natural to combine listening, speaking, reading and writing in a single activity. The students could be required to work alone (be isolated from their classmates) or to perform team work. By using interactive multimedia, the students would become motivated because they felt they had great control over their learning.

The distinctive feature of the EGAP course book was Study-Skills section presented in each unit. This section introduced study skills needed in academic classes. The students would learn how to summarize a reading text, create a writing outline, etcetera. It was hoped that after joining the EGAP course, they could perform those study skills in English in their classes successfully.

In choosing appropriate materials for the course book, ELTC team also paid attention to the general level of the learners' proficiency. Considering the result of the survey which showed that (1) 51.4\% of 1,450 respondents had been learning English for six up to ten years and (2) more than $50 \%$ believed they had fair proficiency, the team assumed that the students' level of English proficiency was Intermediate. This assumption was then evaluated by examining the related literature. Based on Hannon (2008) and SIL International (1998), students of Intermediate level: (1) have already had a basic command of English, (2) can use the language to deal with familiar everyday situations such as introducing themselves, asking questions about personal details, shopping, asking directions, (3) need English for their educational or working life. It could be concluded then that the assumption of the ELTC team concerning the students' level was correct. Therefore, course materials were designed to be accessible and

realistic so that the learners could sustain and maintain motivation and interest.

\section{Course Evaluation}

Upon the completion of the first draft of the EGAP course book, national and local reviewers were invited to elicit feedback for the 
improvement of the draft. Necessary revisions were made accordingly based on the feedback given.

Pilot projects were then conducted in 2006. Inputs were gathered from students and teaching staffs as to how the course could really meet their needs. Classroom observations were also carried out to get an accurate picture of how the EGAP course took place. It was found that in general the respondents were satisfied with the overall course. Nevertheless there were still some minor mistakes such as typographical errors and unclear instructions found in the course book. Necessary revisions were then made by ELTC team.

\section{CONCLUSION}

Based on the opinions of the respondents involved in the study as well as the review of related literature, ELTC team concluded that the materials for the English course at the university should be designed to better meet the students' needs and institutional requirements. The team had tried to develop and tried out such materials in 2005 and 2006. Still further evaluation needs to be conducted on an on-going basis as evaluation is an intrinsic part of teaching and learning.

\section{REFERENCES}

Ahmad, N. (1997). ELT needs and services: Challenges facing ELT providers. In H. Coleman, T. M. Soedradjat, \& G. Westaway (Eds.), Teaching English to university undergraduates in the Indonesian context: Issues and developments (pp. 45-60). Bandung: ITB Press.

Evans, T. D., \& St. John, M. J. (1998). Developments in English for specific purposes. Cambridge: Cambridge University Press.

Floris, F. D. (2004). English as a medium of instruction policy at Petra Christian University: Are the economics teachers ready to implement it? In J. Mukundan, D. Z. Abidin, \& D. S. R. Singh (Eds.), ELT matters 2: Developments in English language learning and teaching (pp. 64-76). Serdang: Universiti Putra Malaysia.

Graves, K. (2000) Designing language courses: A guide for teachers. Boston: Heinle and Heinle.

Hannon, P. (2008). EGL entrance requirements. Retrieved March 5, 2008, from ASCEND: The English Professionals Web site: http://www.ascend. edu.sg/english-as-a-global-language.html\#preintermediate. 
Larsen-Freeman, D. (2000). Techniques and principles in language teaching $\left(2^{\text {nd }}\right.$ ed.). Oxford: Oxford University Press.

McGarry, D. (1995). Learner autonomy 4: The role of authentic texts. Dublin: Authentik.

SIL International. (1998). ACTFL guidelines: Speaking - intermediate. Retrieved March 5, 2008, from SIL International Web site: http://pnglanguages.org/ lingualinks/LANGUAGELEARNING/OtherResources/ACTFLProficienc yGuidelines/ACTFLGuidelinesSpeakingInterme.htm 